\title{
Nutritional enrichment of beef burgers by adding components of non-conventional food plants
}

\section{Enriquecimento nutricional de hambúrguer com adição de componentes de plantas alimentícias não convencionais}

\author{
Valmor Ziegler ${ }^{1 *}$ (D), Mariane Lobo Ugalde ${ }^{2}$, lasmim de Almeida Veeck³, \\ Fabrizio da Fonseca Barbosa ${ }^{4}$
}

${ }^{1}$ Universidade do Vale do Rio dos Sinos (Unisinos), Instituto Tecnológico em Alimentos para a Saúde (itt Nutrifor), São Leopoldo/RS - Brasil

${ }^{2}$ Instituto Federal de Educação, Ciência e Tecnologia Farroupilha (IFFAR), Setor da Agroindústria, campus Júlio de Castilhos, Júlio de Castilhos/RS - Brasil

${ }^{3}$ Instituto Federal de Educação, Ciência e Tecnologia Farroupilha (IFFAR), Curso Técnico em Alimentos, campus Júlio de Castilhos, Júlio de Castilhos/RS - Brasil

${ }^{4}$ Universidade Federal de Pelotas (UFPel), Centro de Ciências Químicas, Farmacêuticas e de Alimentos,

Pelotas/RS - Brasil

${ }^{*}$ Corresponding Author: Valmor Ziegler, Universidade do Vale do Rio dos Sinos, Instituto Tecnológico em Alimentos para a Saúde (itt Nutrifor), Av. Unisinos, 950, Cristo Rei, CEP: 93022-750, São Leopoldo/RS - Brasil, e-mail: valmorziegler12@unisinos.br

Cite as: Ziegler, V., Ugalde, M. L., Veeck, I. A., \& Barbosa, F. F. (2020). Nutritional enrichment of beef burgers by adding components of non-conventional food plants. Brazilian Journal of Food Technology, 23, e2019030. https://doi.org/10.1590/1981-6723.03019

\begin{abstract}
Some non-conventional food plants (NCFPs) such as Yacon potato, Moringa, and Ora-pro-nobis have been studied to identify their constitution and health-promoting substances. The purpose of this study was to enrich the beef burger with unconventional food plant and to evaluate its physical, chemical and sensorial properties. Ten formulations were prepared, being one formulation for the conventional burger (with soy protein and without addition of NCFPs) and nine formulations with variations of $2 \%, 4 \%$ and $6 \%$ of flour of each of the NCFPs. Addition of NCFPs flours improved nutritional burger properties and resulted in an increase in protein, ash, and dietary fiber content, a slight reduction in fats and significant reduction in carbohydrates. The burgers produced using $2 \%$ and $4 \%$ of Yacon flour had the lowest differences in these parameters as compared to those of the conventional burger, and also presented acceptance rates that were similar to that of the conventional burger. Both formulations showed the greatest similarity to the conventional burger during sensory analysis, which could be well accepted by consumers who are looking for healthier foods.
\end{abstract}

Keywords: Burger; Yacon; Moringa; Ora-pro-nobis; Sensory; Acceptance.

\section{Resumo}

Algumas Plantas Alimentares Não Convencionais (PANCs), como a batata Yacon, a Moringa e a Ora-pro-nobis, foram estudadas para identificar a sua constituição e as substâncias promotoras da saúde. O objetivo deste estudo foi enriquecer o hambúrguer bovino com componentes de plantas alimentícias não convencionais e avaliar suas 
propriedades físicas, químicas e sensoriais. Foram elaboradas 10 formulações, sendo uma delas a formulação com proteína de soja (sem adição das PANCs) e nove formulações com variações de $2 \%, 4 \%$ e $6 \%$ de farinha de cada uma das PANCs. A adição da farinha dessas plantas nos hambúrgueres melhorou suas propriedades nutricionais e resultou em um aumento no teor de proteína, cinzas e fibras alimentares, uma ligeira redução nas gorduras e uma redução significativa nos carboidratos. Os hambúrgueres produzidos com $2 \%$ e $4 \%$ de farinha de Yacon apresentaram as menores diferenças nesses parâmetros quando comparados aos do controle e apresentaram taxas de aceitação similares à da formulação controle. Essas duas formulações também apresentaram maior similaridade com a formulação controle durante a análise sensorial, o que evidencia o potencial de serem bem aceitas pelos consumidores que buscam alimentos mais saudáveis.

Palavras-chave: Hambúrguer; Yacon; Moringa; Ora-pro-nobis; Sensorial; Aceitação.

\section{Introduction}

The burger is a meat product that is included in an eating routine of several consumers worldwide, because of its sensory properties and of being easy to prepare. It is defined as a processed meat product this one obtained from the meat of butchered animals, possibly containing additional adipose tissue and ingredients, which is molded and subjected to a suitable technological process and has a chemical composition of at most $23 \%$ of fat content, $3 \%$ of carbohydrate and at least $15 \%$ of protein (Brasil, 2000). The consumption of these processed foods has grown considerably along with an increase in fast food consumption because these foods are easy to prepare, furthermore, meats containing low nutritional content are possible, and they can serve as a vehicle for the addition of nutraceutical components in food (Rodríguez-Carpena et al., 2012; Ozvural \& Huang, 2017).

The changes in processing food and in addition to the increasing demands of consumers for foods that present health-related benefits connected to a high sensorial and nutritional quality raise the need for new ingredients that can meet these market demands and confront new challenges in food technology. In this context, functional foods gain importance because of their potential to promote health through mechanisms that are not observed conventionally. Notably, their use is restricted to health promotion rather than "curing" diseases (Roberfroid et al., 2010). In particular, consumer acceptance of these foods has been recognized as a key factor in negotiating successfully the market opportunities (Siró et al., 2008).

Currently, some plants, such as Yacon potato (Smallanthus sonchifolius) (Genta et al., 2009), Moringa (Moringa oleifera) (Anwar et al., 2007), and Ora-pro-nobis (Pereskia sp) (Kazama et al., 2012; Agostini-Costa et al., 2014) are being studied to determine their functional potential and benefits to health consumer. In addition, the composition of the flours originating from these raw materials includes a considerable level of fiber content, which also contributes to their technological functions, due to their high water retention capacity and fat contents (Choi et al., 2009; Zhao et al., 2018), which helps in the formation of the meaty emulsion, even with low fat content (Shahiri Tabarestani \& Mazaheri Tehrani, 2012).

The worldwide interest in the production of the Yacon potato, mainly shown by alimentary industries, is assigned to the fact that its tuberous root is considered a functional food, which is composed of bioactive compounds and alimentary fibers (mainly inulin), and offers health benefits (Campos et al., 2012; Shoaib et al., 2016). Carbohydrates, fructose, glucose, sucrose, and low grade of oligosaccharides, in particular, can constitute $67 \%$ of the dry matter and are stored in their tuberous roots. The root has a low concentration of proteins and lipids; however, it presents a high calcium and potassium contents and relatively low levels of other minerals (Goto et al., 1995; Rodrigues et al., 2011).

Moringa is a perennial and arboreal species, and its leaves, green fruits, flowers, and roasted seeds have a high amount of nutrients (Okuda et al., 2001). The levels of proteins, bioactive compounds, vitamins, and minerals are significant, and it is considered as one of the best perennial vegetables (Rufai et al., 2018). The leaves have a pleasant, slightly spicy taste and can be included in soups, stews, and varied dishes. Moringa leaves are used as an alternative medicine, mainly for economic and social reasons, owing to their anti-inflammatory, analgesic, anti-asthmatic, anti-anemic, anti-spasmolytic and edema inhibiting activities, 
as well as metabolism activating, purifying, liver protective, hypotensive,, hormone producing, body fluid mobilizing (homeostatic), detoxifying, muscle and bone strengthening, increased mental alertness, memory and learning stimulating and diuretic effects (Anwar et al., 2007; Gupta et al., 2018; Falowo et al., 2018).

Ora-pro-nobis is an unconventional vegetable that is rich in nutrients such as minerals, vitamins, and proteins, whose inclusion in the daily diet is recommended; it can be consumed in both raw and processed forms. This vegetable has juicy and edible leaves, and can be used in various preparations, such as dairy drinks, flours, salads, sausages, pies, and pastas, as well as for the production of juices, jellies, liqueurs, and ice creams. In addition, the leaves exhibited a high protein (22.93\% dry basis) and fiber (12.64\%) contents, and a significant amount of iron and calcium (Takeiti et al., 2009; Kazama et al., 2012; Pinto \& Scio 2014; Amaral et al., 2018).

Functional foods have a prominent position in food technology research, and consumer interest in preparing health foods has increased. In addition to providing nourishment, functional foods also contribute to the improvement of health as a whole. Thus, the development of a burger enriched with health promoting nutrients stands out as a differential of this study. In this context, the purpose of this study was to enrich the beef burger with unconventional food plant components and to evaluate its physicochemical and sensorial properties.

\section{Material and methods}

\subsection{Raw materials and ingredients}

The beef used in this experiment, known as a soft mattress, was a cut obtained from the hind and was purchased in the local trade center of Júlio de Castilhos/Rio Grande do Sul State (RS), which was duly legalized and supervised for this purpose. Yacon flour was obtained by the dehydration of the potato, Moringa and Ora-pro-nobis flours in which were obtained by the dehydration of the leaves using an oven with sufficient air circulation, at a temperature of $55^{\circ} \mathrm{C}$. Subsequently, a milling process was carried out to obtain flour using 30-mesh granulometry. The dehydration time was $5 \mathrm{~h}$ for Moringa and Ora-pro-nobis leaves, and $8 \mathrm{~h}$ for Yacon. The flours were packed in polyethylene bags and stored under refrigerated conditions, until the burgers were prepared. The moisture content of the flours used for burger preparation was $6 \pm 0.5 \%$. All the other ingredients used in the formulations were purchased locally (Júlio de Castilhos/RS), and all the procedures for the enrichment of the burger were in accordance with good manufacturing practices.

Ten different burger formulations were prepared, as shown in Table 1. Formulation 1 (F1) contains $5 \%$ of Textured Soy Protein (TSP) (conventional burger), and no flour was added to it. According to the other formulations, the concentrations of $2 \%, 4 \%$, and $6 \%$ of each of the flours were tested without adding TSP. The added flours would be responsible for the technological function of meat emulsion formation. All ingredients, except flours, were added in the same concentration in all formulations.

Table 1. Concentration of ingredients used to make $1 \mathrm{~kg}$ of each formulation.

\begin{tabular}{|c|c|c|c|c|c|c|c|c|c|c|}
\hline \multirow{2}{*}{ Ingredients (\%) } & \multicolumn{10}{|c|}{ Weight of ingredients for each formulation (g) } \\
\hline & F1 & F2 & F3 & F4 & F5 & F6 & F7 & F8 & F9 & F10 \\
\hline Meat (75) & 750 & 750 & 750 & 750 & 750 & 750 & 750 & 750 & 750 & 750 \\
\hline Pork fat (10) & 100 & 100 & 100 & 100 & 100 & 100 & 100 & 100 & 100 & 100 \\
\hline Cold water (10) & 100 & 100 & 100 & 100 & 100 & 100 & 100 & 100 & 100 & 100 \\
\hline Conventional burger (5) & 50 & & & & & & & & & \\
\hline Flours $(2,4$ or 6$)$ & & 20 & 40 & 60 & 20 & 40 & 60 & 20 & 40 & 60 \\
\hline Salt (1.5) & 15 & 15 & 15 & 15 & 15 & 15 & 15 & 15 & 15 & 15 \\
\hline Black pepper $(0.07)$ & 0.7 & 0.7 & 0.7 & 0.7 & 0.7 & 0.7 & 0.7 & 0.7 & 0.7 & 0.7 \\
\hline Ground garlic (0.08) & 0.8 & 0.8 & 0.8 & 0.8 & 0.8 & 0.8 & 0.8 & 0.8 & 0.8 & 0.8 \\
\hline Monosodium glutamate (MSG) (0.05) & 0.5 & 0.5 & 0.5 & 0.5 & 0.5 & 0.5 & 0.5 & 0.5 & 0.5 & 0.5 \\
\hline
\end{tabular}

F1- Conventional burger, F2- 2\% flour of Yacon, F3- 4\% flour of Yacon, F4- 6\% flour of Yacon, F5- 2\% flour of Ora-pro-nobis, F6- 4\% flour of Ora-pro-nobis, F7- $6 \%$ flour of Ora-pro-nobis, F8- 2\% flour of Moringa, F9- 4\% flour of Moringa, F10- $6 \%$ flour of Morinha. 
The burgers were prepared by grinding the meat and pork fat, in disks with diameters of $5 \mathrm{~mm}$. After milling, all ingredients were mixed manually $(10 \mathrm{~min})$ by hand and the burgers were molded using a petri plate ( $7 \mathrm{~cm}$ diameter and $1 \mathrm{~cm}$ thick), and the weight of each burger was approximately $50 \mathrm{~g}$. The burgers were then packed in polyethylene bags and stored in a freezer at $-18{ }^{\circ} \mathrm{C}$ until physicochemical analysis and preparation for sensory analysis.

\subsection{Parameters evaluated in flours and burgers}

\subsubsection{Centesimal composition}

The moisture content was determined by oven drying at $105{ }^{\circ} \mathrm{C}$ (Association of Official Analytical Chemists, 2005) and the results were expressed as percentage values. The protein content was determined by the Micro-Kjeldahl method (Association of Official Analytical Chemists, 2005) and the results were expressed as percentage values. The fat content was determined in Soxhlet method for the flour (Association of Official Analytical Chemists, 2005) and by butyrometer for burgers according to the method described in Brasil (1981) and the results were expressed as percentage values. The ash content was determined in a muffle at $550{ }^{\circ} \mathrm{C}$ (Association of Official Analytical Chemists, 2005) and the results were expressed as percentage values. The dietary fiber content of the flours was determined according to the procedure outlined by the AOAC (Association of Official Analytical Chemists, 2005), and the burger content was expressed through a relationship with the dietary fiber concentrations, determined in the flour and textured soy protein, after assuming that none of the other added ingredients could be a source of dietary fiber. The non-fibrous carbohydrate (NFC) content of burgers was determined by using the following equation: 100 - (\% moisture $+\%$ protein $+\%$ fat $+\%$ ash $+\%$ dietary fiber), and the results were expressed as percentage values.

\subsubsection{Visual appearance and colorimetric profile}

The visual appearance of the pre-cooked burgers was recorded using a professional camera.

The colorimetric profile of pre- and post-cooked burgers was determined using a colorimeter (Minolta konica 400/410, Osaka, Japão), which evaluates colors in a three-dimensional system. The parameters used included $L^{*}(100=$ White and $0=$ black $), a^{*}($ positive $=$ red and negative $=$ green $)$ and $b^{*}($ positive $=$ yellow and negative $=$ blue $)$.

\subsubsection{Sensory analysis}

A sensory evaluation was performed after the project was approved by the ethics committee (68907417.8.0000.5574). Fifty untrained judges of both sexes ( 22 men and 28 women), with ages ranging from 18 to 50 years were included; these individuals were students, administrative technicians, and teachers of the "Instituto Federal Farroupilha" - campus Júlio de Castilhos/RS.

For the sensory analysis, the burgers were cooked in a suitable metal plate, and cooking was interrupted when the internal temperature of the hamburgers reached $73{ }^{\circ} \mathrm{C}$. Two sensory tests were performed when the burgers were ready for consumption. The first test was related to the conventional burger difference test (burger without added flour), conducted using a scale from 0 to 8 , with 0 representing "no difference" and 8 representing "extremely different" (Instituto Adolfo Lutz, 2008). This test was applied to evaluate the color, taste, aroma, and texture. The second test was the acceptance test, conducted by using a hedonic scale of 9 points, with 1 representing "very much disgusted" and 9 representing "I liked it very much". The samples were randomly delivered to the evaluators. Each evaluator individually performed the tests in appropriate booths, without interference from the other evaluators, and the results were expressed by the average of points designated by all the judges. 


\subsection{Statistical analysis}

Random design was used. All analyses were performed in triplicate, except the sensorial analysis, and the results were subjected to statistical analysis by the Analysis of Variance (ANOVA) method, followed by the comparison of means by the Tukey's test at $5 \%$ probability $(p \leq 0.05)$.

\section{Results and discussion}

\subsection{Centesimal composition of flours and burgers}

The centesimal composition (dry basis) of the Yacon, Moringa, and Ora-pro-nobis flours included 71.77, 13.83 and $1.71 \%$ of NFC, $21.03,48.21$ and $55.39 \%$ of food fibers, $4.67,7.75$ and $16.34 \%$ of ash, 1.96, 24.79 and $22.41 \%$ of protein, and $0.57,4.54$ and $3.27 \%$ of fat content, respectively.

The centesimal composition of burgers prepared with different concentrations of Yacon, Moringa, and Ora-pro-nobis flours is shown in Table 2. The conventional burger presented $66.84 \%$ of moisture, $14.70 \%$ of protein, $7.34 \%$ of fats, $1.77 \%$ of ash, $1.00 \%$ regarding dietary fibers, and $8.34 \%$ of NFC, furthermore, these results were similar to those obtained by Mizi et al. (2018) who produced a beef burger with $71.96 \%$ of moisture, $6.20 \%$ of fat contents, $19.12 \%$ of protein, and $1.94 \%$ of ash.

Table 2. Centesimal composition of beef burgers to which different concentrations of Yacon, Moringa or Ora-pronobis flours were added.

\begin{tabular}{|c|c|c|c|}
\hline Concentration of flour $(\%)$ & Yacon & Moringa & Ora-pro-nobis \\
\hline \multicolumn{4}{|c|}{ Moisture (\%) } \\
\hline Conventional burger (5\%) & A $66.84 \pm 0.61 b^{*}$ & A $66.84 \pm 0.61 \mathrm{~b}$ & A $66.84 \pm 0.61 \mathrm{a}$ \\
\hline 2 & A $69.65 \pm 0.49 \mathrm{a}$ & $\mathrm{AB} 68.43 \pm 1.07 \mathrm{ab}$ & B $66.64 \pm 0.86 \mathrm{a}$ \\
\hline 4 & A $68.16 \pm 0.95 \mathrm{ab}$ & A $69.28 \pm 0.39 \mathrm{a}$ & A $67.54 \pm 0.64 \mathrm{a}$ \\
\hline 6 & A $68.78 \pm 0.54 \mathrm{a}$ & B $66.93 \pm 0.10 \mathrm{~b}$ & $\mathrm{AB} 67.84 \pm 0.77 \mathrm{a}$ \\
\hline \multicolumn{4}{|c|}{ Protein $(\%)$} \\
\hline Conventional burger (5\%) & A $14.70 \pm 0.74 \mathrm{a}$ & A $14.70 \pm 0.74 b$ & A $14.70 \pm 0.74 b$ \\
\hline 2 & B $12.34 \pm 0.29 \mathrm{a}$ & A $14.69 \pm 0.27 \mathrm{~b}$ & A $14.16 \pm 0.29 b$ \\
\hline 4 & A $14.21 \pm 0.63 \mathrm{a}$ & A $15.44 \pm 0.20 \mathrm{~b}$ & A $15.90 \pm 0.48 \mathrm{~b}$ \\
\hline 6 & B $14.70 \pm 0.84 \mathrm{a}$ & AB $16.38 \pm 0.15 \mathrm{a}$ & A $18.33 \pm 0.16 \mathrm{a}$ \\
\hline \multicolumn{4}{|c|}{ Fat $(\%)$} \\
\hline Conventional burger $(5 \%)$ & A $7.34 \pm 0.31 \mathrm{a}$ & A $7.34 \pm 0.31 \mathrm{a}$ & A $7.34 \pm 0.31 \mathrm{a}$ \\
\hline 2 & A $7.35 \pm 0.22 \mathrm{a}$ & A $7.61 \pm 0.34 \mathrm{a}$ & A $7.69 \pm 0.12 \mathrm{a}$ \\
\hline 4 & A $7.14 \pm 0.42 \mathrm{a}$ & A $7.18 \pm 0.77 \mathrm{a}$ & A $7.41 \pm 0.51 \mathrm{a}$ \\
\hline 6 & A $7.15 \pm 0.31 \mathrm{a}$ & A $7.06 \pm 0.30 \mathrm{a}$ & A $6.57 \pm 0.39 \mathrm{a}$ \\
\hline \multicolumn{4}{|c|}{ Ash (\%) } \\
\hline Conventional burger $(5 \%)$ & A $1.77 \pm 0.01 \mathrm{ab}$ & A $1.77 \pm 0.01 \mathrm{c}$ & A $1.77 \pm 0.01 \mathrm{c}$ \\
\hline 2 & A $1.76 \pm 0.03 \mathrm{~b}$ & A $1.81 \pm 0.06 \mathrm{bc}$ & A $1.87 \pm 0.04 \mathrm{c}$ \\
\hline 4 & B $1.87 \pm 0.07 \mathrm{ab}$ & B $1.93 \pm 0.06 \mathrm{ab}$ & A $2.22 \pm 0.05 \mathrm{~b}$ \\
\hline 6 & B $1.88 \pm 0.01 \mathrm{a}$ & B $1.97 \pm 0.06 \mathrm{a}$ & A $2.39 \pm 0.08 \mathrm{a}$ \\
\hline \multicolumn{4}{|c|}{ Food Fiber (\%) } \\
\hline Conventional burger $(5 \%)$ & A $1.00 \pm 0.00 \mathrm{~b}$ & A $1.00 \pm 0.00 \mathrm{c}$ & A $1.00 \pm 0.00 \mathrm{~d}$ \\
\hline 2 & $\mathrm{C} 0.42 \pm 0.00 \mathrm{~d}$ & B $0.96 \pm 0.00 \mathrm{~d}$ & A $1.10 \pm 0.00 \mathrm{c}$ \\
\hline 4 & $\mathrm{C} 0.84 \pm 0.00 \mathrm{c}$ & B $1.92 \pm 0.00 \mathrm{~b}$ & A $2.21 \pm 0.00 \mathrm{~b}$ \\
\hline 6 & $\mathrm{C} 1.26 \pm 0.00 \mathrm{a}$ & B $2.89 \pm 0.00 \mathrm{a}$ & A $3.32 \pm 0.00 \mathrm{a}$ \\
\hline \multicolumn{4}{|c|}{ Non-fibrous carbohydrates $(\%)$} \\
\hline Conventional burger $(5 \%)$ & A $8.34 \pm 0.31 \mathrm{a}$ & A $8.34 \pm 0.31 \mathrm{a}$ & A $8.34 \pm 0.31 \mathrm{a}$ \\
\hline 2 & A $8.47 \pm 0.55 \mathrm{a}$ & B $6.41 \pm 0.78 \mathrm{~b}$ & A $8.61 \pm 0.82 \mathrm{a}$ \\
\hline 4 & A $7.78 \pm 0.56 \mathrm{ab}$ & B $4.00 \pm 0.61 \mathrm{c}$ & B $4.93 \pm 0.42 b$ \\
\hline 6 & A $6.22 \pm 1.20 \mathrm{~b}$ & A $5.25 \pm 0.17 \mathrm{bc}$ & B $1.05 \pm 0.90 \mathrm{c}$ \\
\hline
\end{tabular}

* For each parameter, simple arithmetic means of three replicates \pm standard deviation, followed by different lowercase letters in the same column, and upper case in the same row, differ by Tukey test $(p \leq 0.05)$. 
The moisture content (Table 2) of burgers prepared with different concentrations of flour (Yacon, Moringa, and Ora-pro-nobis) did not present noticeable changes in the function of that type of flour, and also in the concentration at which it was used. The protein content did not show a difference $(p \leq 0.05)$ concerning the function related to the concentration of Yacon flour. However, for the burger prepared with $6 \%$ of Moringa and Ora-pro-nobis, there was an increase $(p \leq 0.05)$ in protein content, from $14.70 \%$ (control) to 16.38 and $18.33 \%$, respectively, for the Moringa and Ora-pro-nobis flours. The increased protein content found in burgers with $6 \%$ of Moringa and Ora-pro-nobis flours are a result of this high protein content found in the respective flours.

The fat content (Table 2) did not change significantly $(p \leq 0.05)$ as a function of the concentration and the flour used, while the ash content in the burgers (Table 2$)$ increased $(p \leq 0.05)$. The highest ash concentration of $2.39 \%$ occurred in the burger composed of $6 \%$ of Ora-pro-nobis flour, as compared to the control, with $1.77 \%$ of ash content. This increase in ash content is due to the higher concentration of ash present in the Ora-pro-nobis flour (16.34\%), which was added to the burger. The increase in ash content was also verified by Choi et al. (2009) in a meat emulsion prepared by using $2 \%$ of rice bran fiber, as compared to a formulation prepared without the addition of rice bran fiber.

The dietary fiber content (Table 2) was significantly increased $(p \leq 0.05)$ in all formulations in which $6 \%$ of flour was used, and the highest percentage increase of 3.32\% was found in the burger with $6 \%$ of Ora-pro-nobis flour, while the conventional burger presented $1.00 \%$ of dietary fiber. Sánchez-Zapata et al. (2010) emphasized that the increase in fiber content through the addition of fiber-rich flours is important, because it improves the functional properties of the burger, a food traditionally known not to present these characteristics. Dietary fibers are known to aid in cholesterol reduction, in addition to having prebiotic functions (Elleuch et al., 2011). In the case of burgers formulated with Yacon flour, burgers could alternatively be enriched with inulin, which is known to have broad health benefits (Shoaib et al., 2016).

The NFC content (Table 2$)$ was reduced $(p \leq 0.05)$ with an increase in the flour concentration, regardless of the species used, with the highest reductions observed in the burger prepared using $6 \%$ of Ora-pro-nobis flour. Considering that NFC are calculated based on differences in the levels of other constituents, it was expected that the burger prepared with $6 \%$ of Ora-pro-nobis flour would present the lowest value, since it showed the highest values of proteins, ash, and fiber to feed. These results are also relevant, because the lower NFC index, the lower glycemic index of this product will be.

In general, an increase in the amount of flour in burgers improved the nutritional properties of them, and lead to an increase in the protein, ash, and dietary fiber content, with a slight reduction in fat (although not significant $(p \geq 0.05)$ and significant reduction in NFC content.

\subsection{Visual appearance and colorimetric profile}

Figure 1 shows the visual appearance of pre-cooked burgers. It was observed that the conventional burger showed a reddish color, being characteristic of traditional beef burgers, whereas the burgers enriched with flours had a darker color, because of the increase in the concentration of the flour, as compared to the control. 


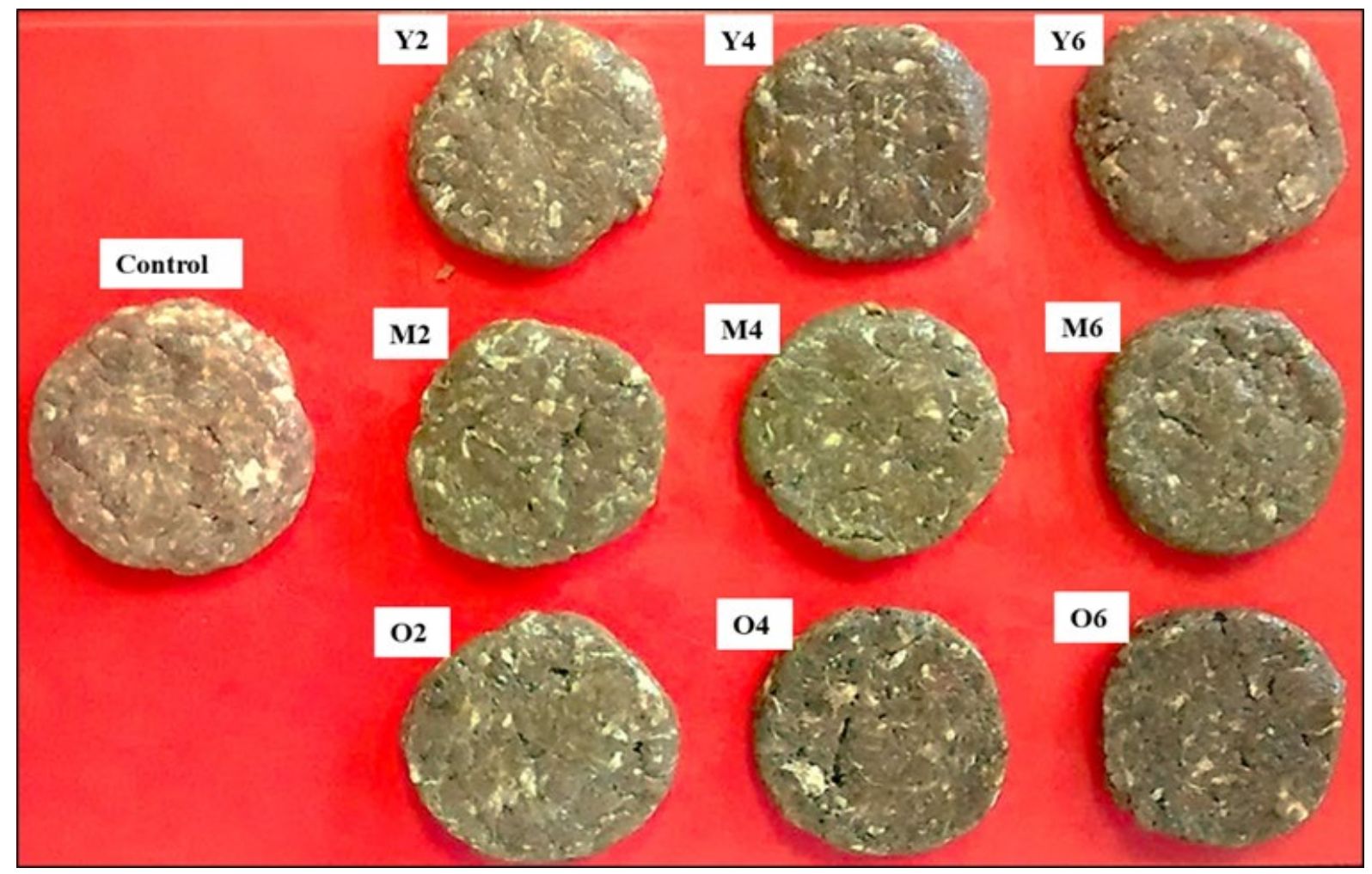

Figure 1. Beef burgers with different concentrations of Yacon, Moringa, and Ora-pro-nobis flour. Here, Y2 - Yacon 2\%, Y4 - Yacon 4\%, Y6 - Yacon 6\%, M2 - Moringa 2\%, M4 - Moringa 4\%, M6 - Moringa 6\%, O2 - Ora-pro-nobis 2\%, O4 - Ora-pro-nobis 4\% and O6 - Ora-pro-nobis 6\%.

In addition to the visual appearance, the colorimetric profile of the burgers was also measured to identify the changes in coloration occurring with increased flour content, and the results of the colorimetric profile, obtained pre-cooking, are presented in Table 3. A significant reduction $(p \leq 0.05)$ in the $\mathrm{L}^{*}$ value was observed with an increase in the flour concentration, independent of the flour type used. While comparing the $6 \%$ added flours, the largest reduction in the $\mathrm{L}^{*}$ value from 43.02 (conventional burger) to 34.20 was observed for the Ora-pro-nobis flour. These results demonstrated that the burgers became darker with an increase in the flour concentration, as shown in Figure 1. Similar results were obtained by Selani et al. (2016) after adding $1.5 \%$ of a pineapple by-product in beef burgers.

A significant reduction $(p \leq 0.05)$ in the $a^{*}$ value (Table 3 ) was observed with an increase in the flour concentration, with the greatest reductions in a* value observed for Moringa and Ora-pro-nobis flours, at a concentration of $6 \%$. These results demonstrated that the burgers lost their reddish coloration, a characteristic of the traditional burger, as shown in Figure 1. This behavior is expected when other non-meat ingredients are added to the burger, and similar behavior was observed by Sánchez-Zapata et al. (2010) in pork burgers to which tiger nut fibers were added.

A significant reduction $(p \leq 0.05)$ in the $b^{*}$ value (Table 3$)$ was observed with an increase in flour concentration, regardless of the type of flour. These results demonstrated that the yellow coloration of the burgers was reduced, which was in agreement with the reduction in $\mathrm{L}^{*}$ and $\mathrm{a}^{*}$ values. Reductions in the $\mathrm{b}^{*}$ value were also observed by Sayago-Ayerdi et al. (2009), after adding dietary fiber from grapes into chicken burgers.

The results of the colorimetric profile of beef burgers, post-cooking, are presented in Table 3. In general, the same trend was observed in pre-cooked burgers, with a reduction in $\mathrm{L}^{*}, \mathrm{a}^{*}$, and $\mathrm{b}^{*}$ values, nevertheless, with an increase in the flour concentration used, in relation to the conventional burger. However, it is worth noting that the differences were not as pronounced as in pre-cooked burgers, probably due to the compounds 
formed during the thermal process. Similar behavior was also reported by Selani et al. (2016) while adding pineapple by-products in beef burgers, who observed a reduction in color differences after cooking, which was attributable to the addition of non-meat ingredients. Sánchez-Zapata et al. (2010) also obtained similar results while producing burgers containing added tiger nut fibers. The compounds that impart a characteristic color to heat-treated products are produced because of the Maillard reaction, owing to the caramelization of carbohydrates, and the oxidation of fats (Sánchez-Zapata et al., 2010; Soncu \& Kolsarici, 2016). Heat treatment reduced the effects of flour addition on the colorimetric profile, which is an advantageous factor, considering that the product would be consumed after cooking. Thus, it helps to inhibit the negative effects of product appearance, which resulted from the addition of flour.

Table 3. Colorimetric profile of beef burgers to which different concentrations of Yacon, Moringa, or Ora-pro-nobis flour was added, pre- and post-cooking.

\begin{tabular}{|c|c|c|c|c|c|c|}
\hline \multirow{2}{*}{$\%$ of flour } & \multicolumn{3}{|c|}{ Pre-cooking } & \multicolumn{3}{|c|}{ Post-cooking } \\
\hline & Yacon & Moringa & Ora-pro-nobis & Yacon & Moringa & Ora-pro-nobis \\
\hline & \multicolumn{3}{|c|}{ Value $L^{*}$} & \multicolumn{3}{|c|}{ Value $L^{*}$} \\
\hline $\begin{array}{c}\text { Conventional } \\
\text { burger }(5 \%)\end{array}$ & A $43.02 \pm 0.60 \mathrm{a}^{* *}$ & A $43.02 \pm 0.60 \mathrm{a}$ & A $43.02 \pm 0.60 \mathrm{a}$ & A $31.38 \pm 1.61 \mathrm{a}$ & A $31.38 \pm 1.61 \mathrm{a}$ & A $31.38 \pm 1.61 \mathrm{a}$ \\
\hline 2 & A $40.13 \pm 0.41 \mathrm{~b}$ & B $37.82 \pm 0.76 \mathrm{~b}$ & A $40.48 \pm 0.81 \mathrm{~b}$ & A $32.82 \pm 1.92 \mathrm{a}$ & A $33.84 \pm 3.43 \mathrm{a}$ & B $28.00 \pm 1.28 \mathrm{~b}$ \\
\hline 4 & A $35.91 \pm 1.35 \mathrm{c}$ & A $36.53 \pm 0.48 \mathrm{c}$ & A $36.02 \pm 0.46 \mathrm{c}$ & $\mathrm{AB} 28.55 \pm 1.49 \mathrm{~b}$ & A $30.70 \pm 2.31 \mathrm{a}$ & B $27.51 \pm 0.72 b$ \\
\hline \multirow[t]{2}{*}{6} & A $35.79 \pm 0.89 \mathrm{c}$ & A $35.54 \pm 0.58 \mathrm{c}$ & B $34.20 \pm 1.03 \mathrm{~d}$ & A $30.87 \pm 1.70 \mathrm{ab}$ & A $32.60 \pm 2.38 \mathrm{a}$ & B $26.72 \pm 0.37 \mathrm{~b}$ \\
\hline & \multicolumn{3}{|c|}{ Value $a^{*}$} & \multicolumn{3}{|c|}{ Value $a^{*}$} \\
\hline $\begin{array}{l}\text { Conventional } \\
\text { burger }(5 \%)\end{array}$ & A $15.89 \pm 0.57 \mathrm{a}$ & A $15.89 \pm 0.57 \mathrm{a}$ & A $15.89 \pm 0.57 \mathrm{a}$ & A $6.19 \pm 0.55 \mathrm{a}$ & A $6.19 \pm 0.55 \mathrm{a}$ & A $6.19 \pm 0.55 \mathrm{a}$ \\
\hline 2 & A $4.62 \pm 0.34 \mathrm{~b}$ & B $3.29 \pm 0.52 b$ & $\mathrm{C} 1.70 \pm 0.88 \mathrm{~b}$ & A $5.16 \pm 0.32 b$ & B $2.58 \pm 1.00 \mathrm{~b}$ & B $3.22 \pm 0.17 \mathrm{~b}$ \\
\hline 4 & A $3.89 \pm 0.35 \mathrm{c}$ & B $0.34 \pm 0.96 \mathrm{c}$ & $\mathrm{B}-0.15 \pm 0.43 \mathrm{c}$ & A $4.07 \pm 0.51 \mathrm{c}$ & B $1.58 \pm 1.14 \mathrm{bc}$ & B $1.79 \pm 0.44 \mathrm{c}$ \\
\hline \multirow[t]{2}{*}{6} & A $3.90 \pm 0.23 \mathrm{c}$ & B $-1.24 \pm 0.94 \mathrm{~d}$ & $\mathrm{~B}-0.26 \pm 0.96 \mathrm{c}$ & A $4.37 \pm 0.40 \mathrm{c}$ & B $0.30 \pm 0.57 \mathrm{c}$ & B $0.95 \pm 0.26 \mathrm{~d}$ \\
\hline & \multicolumn{3}{|c|}{ Value $b^{*}$} & \multicolumn{3}{|c|}{ Value $b^{*}$} \\
\hline $\begin{array}{c}\text { Conventional } \\
\text { burger }(5 \%)\end{array}$ & A $14.38 \pm 0.45 \mathrm{a}$ & A $14.38 \pm 0.45 \mathrm{a}$ & A $14.38 \pm 0.45 \mathrm{a}$ & A $11.61 \pm 1.29 \mathrm{ab}$ & A $11.61 \pm 1.29 \mathrm{a}$ & A $11.61 \pm 1.29 \mathrm{a}$ \\
\hline 2 & B $13.14 \pm 0.24 b$ & B $11.93 \pm 0.62 \mathrm{ab}$ & B $12.03 \pm 0.41 \mathrm{~b}$ & A $12.11 \pm 1.49 \mathrm{a}$ & A $12.67 \pm 1.78 \mathrm{a}$ & B $8.59 \pm 0.97 b$ \\
\hline 4 & A $10.60 \pm 0.80 \mathrm{~d}$ & A $12.62 \pm 3.64 \mathrm{ab}$ & A $11.11 \pm 1.11 \mathrm{bc}$ & B $10.17 \pm 0.59 \mathrm{~b}$ & A $11.44 \pm 1.12 \mathrm{a}$ & $\mathrm{C} 7.36 \pm 0.63 \mathrm{bc}$ \\
\hline 6 & A $11.59 \pm 0.29 \mathrm{c}$ & A $10.50 \pm 2.41 \mathrm{~b}$ & A $10.17 \pm 0.54 \mathrm{c}$ & A $10.41 \pm 0.97 \mathrm{ab}$ & A $10.65 \pm 1.36 \mathrm{a}$ & B $6.44 \pm 0.55 \mathrm{c}$ \\
\hline
\end{tabular}

* For each parameter and for each pre- and post-cooking, simple arithmetic means of three replicates \pm standard deviation, followed by different lowercase letters in the same column, and upper case in the same row, differ by Tukey's test $(p \leq 0.05)$.

\subsection{Sensory analysis}

\subsubsection{Difference of conventional burger and acceptance}

Table 4 presents the results of the sensory test, which show the differences between burgers prepared with different concentrations of Yacon, Moringa, and Ora-pro-nobis flours and conventional burger. It is observed that when 2\% of Yacon flour was used, the values varied between 2 and 3 for parameters such as color, flavor, aroma, and texture, which showed that the burgers were classified as being "slightly different" from the control. With an increase in the flour concentration, the values for color, flavor, and texture were significantly increased $(p \leq 0.05)$, and with the addition of $6 \%$ of Yacon flour, these values were 3.31, 5.18, and 3.68, respectively. 
Table 4. Difference tests of conventional burger and acceptance tests of burgers with different concentrations of Yacon, Moringa, or Ora-pro-nobis flours.

\begin{tabular}{|c|c|c|c|c|c|c|}
\hline $\begin{array}{c}\text { Concentration } \\
\text { of flour } \\
(\%) \\
\end{array}$ & Color & Flavor & Aroma & Texture & $\begin{array}{c}\begin{array}{c}\text { Concentration of } \\
\text { flour } \\
(\%)\end{array} \\
\end{array}$ & $\begin{array}{c}\text { Acceptance } \\
(\%)\end{array}$ \\
\hline Yacon & & & & & $\begin{array}{c}\text { Conventional burger } \\
(5 \%)\end{array}$ & $86.36 \pm 11.67 \mathrm{a}^{*}$ \\
\hline 2 & $2.04 \pm 1.81 \mathrm{~b}^{*}$ & $2.84 \pm 2.13 \mathrm{~b}$ & $2.04 \pm 1.89 \mathrm{a}$ & $2.31 \pm 2.09 \mathrm{~b}$ & 2 & $74.49 \pm 21.2 \mathrm{bc}$ \\
\hline 4 & $3.59 \pm 2.26 \mathrm{a}$ & $3.88 \pm 2.28 \mathrm{~b}$ & $2.36 \pm 1.96 \mathrm{a}$ & $2.50 \pm 1.84 \mathrm{~b}$ & 4 & $78.53 \pm 17.99 \mathrm{ab}$ \\
\hline 6 & $3.31 \pm 1.83 \mathrm{a}$ & $5.18 \pm 1.99 \mathrm{a}$ & $2.90 \pm 2.06 \mathrm{a}$ & $3.68 \pm 2.09 \mathrm{a}$ & 6 & $65.65 \pm 21.93 \mathrm{c}$ \\
\hline Moringa & & & & & $\begin{array}{c}\text { Conventional burger } \\
(5 \%)\end{array}$ & $86.36 \pm 11.67 \mathrm{a}$ \\
\hline 2 & $6.22 \pm 2.05 \mathrm{a}$ & $6.25 \pm 1.68 \mathrm{a}$ & $5.40 \pm 2.18 \mathrm{a}$ & $4.31 \pm 2.47 \mathrm{a}$ & 2 & $47.72 \pm 26.96 b$ \\
\hline 4 & $4.13 \pm 2.15 \mathrm{~b}$ & $5.25 \pm 1.96 \mathrm{~b}$ & $4.18 \pm 2.24 \mathrm{~b}$ & $3.43 \pm 2.05 \mathrm{a}$ & 4 & $54.79 \pm 25.40 \mathrm{~b}$ \\
\hline 6 & $5.81 \pm 2.11 \mathrm{a}$ & $6.27 \pm 1.54 \mathrm{a}$ & $4.86 \pm 2.35 \mathrm{ab}$ & $3.75 \pm 2.19 \mathrm{a}$ & 6 & $46.21 \pm 22.34 \mathrm{~b}$ \\
\hline Ora-pro-nobis & & & & & $\begin{array}{c}\text { Conventional burger } \\
(5 \%)\end{array}$ & $86.36 \pm 11.67 \mathrm{a}$ \\
\hline 2 & $3.86 \pm 2.46 \mathrm{a}$ & $4.41 \pm 2.58 \mathrm{~b}$ & $3.13 \pm 2.58 \mathrm{~b}$ & $3.16 \pm 3.02 \mathrm{ab}$ & 2 & $61.61 \pm 27.05 \mathrm{bc}$ \\
\hline 4 & $3.62 \pm 2.28 \mathrm{a}$ & $4.09 \pm 1.94 \mathrm{~b}$ & $3.06 \pm 2.14 \mathrm{~b}$ & $2.60 \pm 1.95 \mathrm{~b}$ & 4 & $67.67 \pm 22.96 \mathrm{~b}$ \\
\hline 6 & $4.20 \pm 2.07 \mathrm{a}$ & $5.58 \pm 1.81 \mathrm{a}$ & $4.44 \pm 2.31 \mathrm{a}$ & $4.02 \pm 2.61 \mathrm{a}$ & 6 & $54.79 \pm 24.36 \mathrm{c}$ \\
\hline
\end{tabular}

* For each flour, simple arithmetic means of 50 replicates \pm standard deviation, followed by different lowercase letters in the same column, differ from each other by the Tukey's test $(p \leq 0.05)$.

In burgers containing $2 \%$ of added Moringa flour, it was observed that the values for color, flavor, aroma, and texture were $6.22,6.25,5.40$, and 4.31 , respectively, which showed that the opinion of the judges ranged from "moderately different" to "very different", for these parameters. No significant changes in the parameters of color, flavor, aroma, and texture were observed as a function of the increase in Moringa flour concentration.

In burgers containing $2 \%$ of added Ora-pro-nobis flour, it was observed that the values for the parameters of color, flavor, aroma, and texture were $3.86,4.41,3.13$, and 3.16, respectively, which showed that the opinion of the judges ranged from "slightly different" to "moderately different", for these parameters. There was no difference $(p \leq 0.05)$ in the scores for color and texture parameters regarding the increase in the flour concentration, but the values for flavor and aroma increased $(p \leq 0.05)$ to 5.58 and 4.44 , respectively, when $6 \%$ of Ora-pro-nobis flour was used, instead of $2 \%$ of added flour. In general, when analyzing the results indicating the differences with respect to the control, according to the evaluators, the addition of Yacon flour resulted in the lowest differences in color, flavor, aroma and texture parameters.

Table 4 presents the acceptance test results of burgers prepared with different concentrations of Yacon, Moringa, and Ora-pro-nobis flours. It was observed that the conventional burger had $86.36 \%$ acceptability. The burgers prepared with $2 \%$ and $4 \%$ of Yacon flour had $74.49 \%$ and $78.53 \%$ of acceptability, respectively, and the formulation with $4 \%$ did not present a significant difference, as compared to the conventional burger $(p \leq 0.05)$. It should be emphasized that for a product to be well accepted, it is necessary for the acceptance rate to be greater than $70 \%$ (Dutcosky, 2013). The formulation containing 6\% of Yacon flour showed a 20.71 percentage point reduction in acceptability.

There was a significant reduction $(p \leq 0.05)$ in the acceptability of burgers prepared using Moringa flour, and values of $47.72,54.79$, and $46.21 \%$, respectively, were obtained using $2 \%, 4 \%$, and $6 \%$ of flour. These results are in agreement with those showing a greater difference between color, flavor, aroma, and texture parameters of these samples and those of the conventional burger (Table 4).

A significant reduction $(p \leq 0.05)$ of acceptability was observed for burgers prepared using Ora-pro-nobis flour, and values of $61.61,67.67$, and $54.79 \%$ were obtained using $2 \%, 4 \%$, and $6 \%$ flour, in relation to those observed in conventional burger. There is a similarity in the acceptability behavior of burgers containing Moringa flour or Ora-pro-nobis. 
In general, the results verified in this study are in agreement with those obtained by Contado et al. (2015) who observed a reduction in taste and overall impression of avocado prepared using $1.73 \%$ of Yacon flour. No significant differences were observed, in sensory properties, in chicken burgers, on adding $0.5 \%, 1.0 \%$, $1.5 \%$, and $2 \%$ dietary fiber from grapes, compared to burgers without grape fiber (Sayago-Ayerdi et al., 2009). Sánchez-Zapata et al. (2010) also prepared a pork burger with added tiger nut fibers $(5 \%, 10 \%$, and $15 \%$ ), and did not observe significant sensorial differences between the formulations with or without fiber addition. It is thus clear that sensory acceptance varies depending on the ingredient and the added concentration, and that traditionally consumed products can also be used to provide ingredients beneficial to human health and well-being.

One of the major challenges of food technology is to produce foods with nutritional, functional, and bioactive properties, without causing major changes in sensory characteristics. In this context, it could be observed the closest formulations to conventional burger were those of burgers produced using $2 \%$ and $4 \%$ of Yacon flour, which could be well accepted by consumers who are looking for healthier foods.

\section{Conclusions}

The burgers produced using different concentrations of Yacon, Moringa, and Ora-pro-nobis flours showed improved nutritional properties, with an increase in the protein, ash, and dietary fiber content and a slight reduction in fats and significant reduction in NFC.

The burgers produced with $2 \%$ and $4 \%$ of Yacon flour showed the lowest differences with regard to the conventional burger for parameters such as color, flavor, aroma and texture and presented similar acceptance rates to those of the conventional burger.

\section{Acknowledgements}

We would like to thank the "Instituto Federal de Educação, Ciência e Tecnologia Farroupilha" - campus Júlio de Castilhos, where the research group could collaborate with individuals from various laboratories for carrying out our experiments.

\section{References}

Agostini-Costa, T. S., Pêssoa, G. K. A., Silva, D. B., Gomes, I. S., \& Silva, J. P. (2014). Carotenoid composition of berries and leaves from a Cactaceae - Pereskia sp. Journal of Functional Foods, 11, 178-184. http://dx.doi.org/10.1016/j.jff.2014.09.015

Amaral, T. N., Junqueira, L. A., Prado, M. E. T., Cirillo, M. A., Abreu, L. R., Costa, F. F., \& Resende, J. L. (2018). Blends of Pereskia aculeata Miller mucilage, guar gum, and gum Arabic added to fermented milk beverages. Food Hydrocolloids, 79, 331342. http://dx.doi.org/10.1016/j.foodhyd.2018.01.009

Anwar, F., Latif, S., Ashraf, M., \& Gilani, A. H. (2007). Moringa oleifera: A food plant with multiple medicinal uses. Phytotherapy Research, 21(1), 17-25. PMid:17089328. http://dx.doi.org/10.1002/ptr.2023

Association of Official Analytical Chemists - AOAC. (2005). Official methods of analysis of AOAC International (Method 985.29). Gaithersburg: AOAC.

Brasil. Ministério da Agricultura, Pecuária e Abastecimento. Secretaria Nacional de Defesa Agropecuária. Laboratório Nacional de Referência Animal - LANARA. (1981, outubro 13). Aprovar os Métodos Analíticos para Controle de Produtos de Origem Animal e seus Ingredientes, constituindo-se em Métodos Microbiológicos e Métodos Físicos e Químicos (Portaria $n^{\circ} 01$, de 07 de outubro de 1981). Diário Oficial da União, Brasília.

Brasil. Ministério da Agricultura, Pecuária e Abastecimento. (2000, julho 31). Aprova os regulamentos técnicos de identidade e qualidade de almôndega, de apresuntado, de fiambre, de hamburguer, de kibe, de presunto cozido e de presunto. Anexo IV: regulamento técnico de identidade e qualidade de hamburguer (Instrução Normativa $n^{\circ} 20$, de 31 de julho de 2000). Diário Oficial da União, Brasília. Retrieved in 2018, April 15, from www.agricultura.gov.br

Campos, D., Betalleluz-Pallardel, I., Chirinos, R., Aguilar-Galvez, A., Noratto, G., \& Pedreschi, R. (2012). Prebiotic effects of yacon (Smallanthus sonchifolius Poepp. \& Endl), a source of fructooligosaccharides and phenolic compounds with antioxidant activity. Food Chemistry, 135(3), 1592-1599. PMid:22953898. http://dx.doi.org/10.1016/j.foodchem.2012.05.088

Choi, Y., Choi, J., Han, D., Kim, H., Lee, M., Kim, H., Jeong, J., \& Kim, C. (2009). Characteristics of low-fat meat emulsion systems with pork fat replaced by vegetable oils and rice bran fiber. Meat Science, 82(2), 266-271. PMid:20416740. http://dx.doi.org/10.1016/j.meatsci.2009.01.019 
Contado, E. W. N. F., Rocha, D. A., Queiroz, E. R., Abreu, C. M. P., \& Ramos, E. M. (2015). Emprego da farinha e do extrato de frutanos de yacon na elaboração de apresuntados. Brazilian Journal of Food Technology, 18(1), 49-58.

http://dx.doi.org/10.1590/1981-6723.3814

Dutcosky, S. D. (2013), Análise sensorial de alimentos (4. ed.). Curitiba: Champagnat.

Elleuch, M., Bedigian, D., Roiseux, O., Besbes, S., Blecker, C., \& Attia, H. (2011). Dietary fibre and fibre-rich by-products of food processing: Characterization, technological functionality and commercial applications: A review. Food Chemistry, 124(2), 411421. http://dx.doi.org/10.1016/j.foodchem.2010.06.077

Falowo, A. B., Mukumbo, F. E., Idamokoro, E. M., Lorenzo, J. M., Afolayan, A. J., \& Muchenje, V. (2018). Multi-functional application of Moringa oleifera Lam. in nutrition and animal food products: A review. Food Research International, 106, 317-334. PMid:29579932. http://dx.doi.org/10.1016/j.foodres.2017.12.079

Genta, S., Cabrera, W., Habib, N., Pons, J., Carillo, I. M., Grau, A., \& Sánchez, S. (2009). Yacon syrup: beneficial effects on obesity and insulin resistance in humans. Clinical Nutrition (Edinburgh, Lothian), 28(2), 182-187. PMid:19254816. http://dx.doi.org/10.1016/j.clnu.2009.01.013

Goto, K., Fukai, K., Hikida, J., Nanjo, F., \& Hara, Y. (1995). Isolation and structural analysis of oligosaccharides from yacon (Polymnia sonchifolia). Bioscience, Biotechnology, and Biochemistry, 59(12), 2346-2347. http://dx.doi.org/10.1271/bbb.59.2346

Gupta, S., Jaina, R., Kachhwaha, S., \& Kotharic, S. L. (2018). Nutritional and medicinal applications of Moringa oleifera Lam.Review of current status and future possibilities. Journal of Herbal Medicine, 11, 1-11. http://dx.doi.org/10.1016/j.hermed.2017.07.003

Instituto Adolfo Lutz. - IAL. (2008). Normas analíticas do Instituto Adolfo Lutz (Vol. 1 - Métodos químicos e físicos para análise de alimentos, 4. ed.). São Paulo: IAL.

Kazama, C. C., Uchida, D. T., Canzi, K. N., Souza, P., Crestani, S., Gasparotto-Junior, A., \& Laverde Junior, A. (2012). Involvement of arginine vaso press in the diuretic and hypotensive effects of Pereskia grandifolia Haw. (Cactaceae). Journal of Ethnopharmacology, 144(1), 86-93. PMid:22960548. http://dx.doi.org/10.1016/j.jep.2012.08.034

Mizi, L., Cofrades, S., Bou, R., Pintado, T., López-Caballerro, M. E., Zaidi, F., \& Jiménez-Colmenero, F. (2018). Antimicrobial and antioxidante effects of combined high pressure processing and sage in beef burger during prolonged chilled storage. Innovative Food Science \& Emerging Technologies, 51, 32-40. http://dx.doi.org/10.1016/j.ifset.2018.04.010

Okuda, T., Baes, A. U., Nishijima, W., \& Okada, M. (2001). Isolation and characterization of coagulant extracted from Moringa oleifera seed by salt solution. Water Research, 35(2), 405-410. PMid:11228992. http://dx.doi.org/10.1016/S00431354(00)00290-6

Ozvural, E. B., \& Huang, Q. (2017). Quality differences of hamburger patties incorporated with encapsulated b carotene both as an additive and edible coating. Journal of Food Processing and Preservation, 42, 1-9. http://dx.doi.org/10.1111/jfpp.13353

Pinto, N. C. C., \& Scio, E. (2014). The biological activities and chemical composition of Pereskia species (Cactaceae): A review. Plant Foods for Human Nutrition (Dordrecht, Netherlands), 69(3), 189-195. PMid:24862084. http://dx.doi.org/10.1007/s11130014-0423-z

Roberfroid, M., Gibson, G. R., Hoyles, L., McCartney, A. L., Rastall, R., Rowland, I., Wolvers, D., Watzl, B., Szajewska, H., Stahl, B., Guarner, F., Respondek, F., Whelan, K., Coxam, V., Davicco, M. J., Léotoing, L., Wittrant, Y., Delzenne, N. M., Cani, P. D., Neyrinck, A. M., \& Meheust, A. (2010). Prebiotic effects: metabolic and health benefits. British Journal of Nutrition, 104(Suppl. 2), 1-63. PMid:20920376. http://dx.doi.org/10.1017/S0007114510003363

Rodrigues, F. C., Castro, S. B., Martino, H. S. D., \& Ferreira, C. L. L. F. (2011). Production and chemical characterization of yacon (Smallanthus sonchifolius) flour. Revista do Instituto Adolfo Lutz, 70, 290-295. http://dx.doi.org/10.1590/s0102053620180209

Rodríguez-Carpena, J. G., Morcuende, D., \& Estévez, M. (2012). Avocado, sunflower and olive oils as replacers of pork back-fat in burger patties: effect on lipid composition, oxidative stability and quality traits. Meat Science, 90(1), 106-115. PMid:21703779. http://dx.doi.org/10.1016/j.meatsci.2011.06.007

Rufai, S., Hanafi, M. M., Rafii, M. Y., Mohidin, H., Kankara, S. S., Hussaini, M. A., \& Syed Rastan, S. O. (2018). Enhancing moringa nutritive value for impoverished populations and healthy wellbeing through proper nutrient enrichment. International Food Research Journal, 25, 1606-1615

Sánchez-Zapata, E., Muñoz, E. C., Fuentes, E., Fernández-López, J., Sendra, E., Sayas, E., Navarro, C., \& Pérez-Alvarez, J. A. (2010). Effects of tiger nut fibre on quality characteristics of pork Burger. Meat Science, 85(1), 70-76. PMid:20374867. http://dx.doi.org/10.1016/j.meatsci.2009.12.006

Sayago-Ayerdi, S. G., Brenes, A., \& Goni, I. (2009). Effect of grape antioxidant dietary fiber on the lipid oxidation of raw and cooked chicken hamburgers. Lebensmittel-Wissenschaft + Technologie, 42(5), 971-976.

http://dx.doi.org/10.1016/j.Iwt.2008.12.006

Selani, M. M., Shirado, G. A., Margiotta, G. B., Saldaña, E., Spada, F. P., Piedade, S. M., Contreras-Castillo, C. J., \& CanniattiBrazaca, S. G. (2016). Effects of pineapple byproduct and canola oil as fat replacers on physicochemical and sensory qualities of low-fat beef Burger. Meat Science, 112, 69-76. PMid:26562792. http://dx.doi.org/10.1016/j.meatsci.2015.10.020

Shahiri Tabarestani, H., \& Mazaheri Tehrani, M. (2012). Optimization of physicochemical properties of low-fat hamburger formulation using blend of soy flour, split-pea flour and wheat starch as part of fat replacer system. Journal of Food Processing and Preservation, 38(1), 278-288. http://dx.doi.org/10.1111/j.1745-4549.2012.00774.x

Shoaib, M., Shehzad, A., Omar, M., Rakha, A., Raza, H., Sharif, H. R., Shakeel, A., Ansari, A., \& Niazi, S. (2016). Inulin: Properties, health benefits and food applications. Carbohydrate Polymers, 147, 444-454. PMid:27178951.

http://dx.doi.org/10.1016/j.carbpol.2016.04.020 
Siró, I., Kápolna, E., Kápolna, B., \& Lugasi, A. (2008). Functional food: product development, marketing and consumer acceptance - A review. Appetite, 51(3), 456-467. PMid:18582508. http://dx.doi.org/10.1016/j.appet.2008.05.060

Soncu, E. D., \& Kolsarici, N. (2016). Microwave thawing and green tea extract efficiency for the formation of acrylamide throughout the production process of chicken burgers and chicken nuggets. Journal of the Science of Food and Agriculture, 97(6), 1790-1797. PMid:27476498. http://dx.doi.org/10.1002/jsfa.7976

Takeiti, C. Y., Antonio, G. C., Motta, L. M. P., Collares-Queiroz, F. P., \& Park, K. J. (2009). Nutritive evaluation of a nonconventional leafy vegetable (Pereskia aculeata Miller). International Journal of Food Sciences and Nutrition, 60(Suppl.1), 148160. PMid:19468927. http://dx.doi.org/10.1080/09637480802534509

Zhao, Y., Hou, Q., Zhuang, X., Wang, Y., Zhou, G., \& Zhang, W. (2018). Effect of regenerated cellulose fiber on the physicochemical properties and sensory characteristics of fat-reduced emulsified sausage. Lebensmittel-Wissenschaft + Technologie, 97, 157-163. http://dx.doi.org/10.1016/j.Iwt.2018.06.053 